\title{
Effects of temperature on development and survival of embryos and on larval production of Chorus giganteus (Lesson, 1829) (Gastropoda: Muricidae)
}

\author{
Efectos de la temperatura en el desarrollo y la supervivencia de embriones y en la producción \\ larval de Chorus giganteus (Lesson, 1829) (Gastropoda: Muricidae) \\ José A. Gallardo ${ }^{1}$ and Juan M. Cancino ${ }^{2}$ \\ ${ }^{1}$ Laboratorio de genética Aplicada, Escuela de Ciencias del Mar, Pontificia Universidad Católica de Valparaíso. \\ Avda. Altamirano 1480, Valparaíso, Chile \\ ${ }^{2}$ Departamento de Ecología Costera, Facultad de Ciencias, Universidad Católica de la Santísima Concepción. \\ Casilla 297, Concepción, Chile \\ jose.gallardo@ucv.cl
}

\begin{abstract}
Resumen.- Chorus giganteus muestra un rápido desarrollo intracapsular en alta temperatura, pero esto tiene como consecuencia una alta mortalidad embrionaria y una baja producción larval. El presente estudio fue realizado para determinar la condición de cultivo óptima para asegurar un rápido desarrollo intracapsular y una alta producción larval. Embriones en tres estados de desarrollo intracapsular (segmentación [ES], segmentación avanzada [LS] y trocófora post ingestión de huevos nutricios [TPI]) fueron aclimatados a $12^{\circ} \mathrm{C}$ y luego incubados a 12,15 y $18^{\circ} \mathrm{C}$ para evaluar la producción larval. El tiempo medio de eclosión incrementó con el aumento de la temperatura, pero el éxito en la eclosión de embriones disminuyó desde $51 \pm 2 \%$ en $12^{\circ} \mathrm{C}$ a $8 \pm 1 \%$ en $18^{\circ} \mathrm{C}$ en embriones ES y desde $53 \pm 2 \%$ en $12^{\circ} \mathrm{C}$ a $20 \pm 0,2 \%$ en $18^{\circ} \mathrm{C}$ en embriones LS. Esta declinación estuvo asociada a un incremento de embriones anormales, los cuales aumentaron desde $14 \pm 2 \%$ en $12^{\circ} \mathrm{C}$ a $46 \pm 3 \%$ en $18^{\circ} \mathrm{C}$ en embriones ES y desde $8 \pm 1 \%$ en $12^{\circ} \mathrm{C}$ a $28 \pm 1 \%$ en $18^{\circ} \mathrm{C}$ en embriones LS. En cambio, la eclosión de embriones TPI varió entre $65-70 \%$ y los embriones anormales solo representaron entre 13 y $20 \%$. Por lo tanto, la probabilidad de producir y liberar larvas normales fue significativamente afectada por el efecto combinado de la temperatura y el estado embrionario inicial de cultivo. Una reducida habilidad para ingerir huevos nutricios quizás da cuenta de la variación en la producción larval.
\end{abstract}

Palabras clave: Desarrollo intracapsular, eclosión, trocofora, velígera, cultivo de moluscos

\section{Introduction}

Muricid snails represent an important resource of Chilean fisheries, with some species approaching over-harvesting due to high demands for these products in international markets. As a response to the limitations imposed on fishery of natural stocks, mass culture in hatcheries is

\begin{abstract}
Chorus giganteus shows faster intracapsular embryonic development at high temperature but this is generally associated with a high embryonic mortality and low larval production. The present study was undertaken to determine the optimal combination of temperature and developmental stage for a successful (faster) larval production at high temperature. Embryos at three stages of intracapsular development (early stage [ES-embryos], late stage [LSembryos] and trochophore post nurse-egg ingestion stage [TPI embryos]) were acclimated at $12^{\circ} \mathrm{C}$ then incubated at 12,15 or $18^{\circ} \mathrm{C}$ to evaluated larval production. The median hatch time was accelerated by increasing water temperature. However, the hatching success of ES- and LS-embryos was compromised by higher temperatures, decreasing from a $51 \pm 2 \%$ at $12^{\circ} \mathrm{C}$ to $8 \pm$ $1 \%$ at $18^{\circ} \mathrm{C}$ in ES-embryos and from $53 \pm 2 \%$ at $12^{\circ} \mathrm{C}$ to $20 \pm$ $0.2 \%$ at $18^{\circ} \mathrm{C}$ in LS-embryos. The incidence of developmental abnormality increased with temperature from $14 \pm 2 \%$ at $12^{\circ} \mathrm{C}$ to $46 \pm 3 \%$ at $18^{\circ} \mathrm{C}$ in ES-embryos and from $8 \pm 1 \%$ at $12^{\circ} \mathrm{C}$ to $28 \pm 1 \%$ at $18^{\circ} \mathrm{C}$ in LS-embryos. By contrast, hatching success of TPI embryos ranged from $65-70 \%$ and the incidence abnormality was only between 13 and $20 \%$, with both factors being independent of temperature. Thus the probability of producing and releasing normal larvae was significantly affected by the combined effect of temperature and embryonic stage at the initiation of the culture. A reduced ability to ingest nurse eggs may account for the variation in larval production between the trials.
\end{abstract}

Key words: Intracapsular development, hatching, trochophore, veliger, molluscan aquaculture

being considered as an alternative source for such products (DiSalvo 1988, DiSalvo \& Carriker 1994, Leiva et al. 1998, Carrasco et al. 2006). However, efforts to culture the most valuable and most intensively researched muricid, Concholepas concholepas, produced discouraging results due to its extended planktotrophic larval phase and inadequacy to available culture methods 
(DiSalvo 1988). The muricid Chorus giganteus (Lesson, 1829), seems more suitable to mass culture than $C$. concholepas since the whole embryonic development takes place in 60-100 days. It occurs within the egg capsule containing nurse eggs, which are consumed by the ingesting trochophore stage (González \& Gallardo 1999). Further Martinez et al. (2008) conclude that these larvae have the ability to obtain exogenous dissolved food and to incorporate it into metabolizable compounds. At completion 150-300 lecithotrophic larvae of 900-1000 $\mu \mathrm{m}$ shell length, emerge from each egg capsule (Gallardo 1981, Leiva et al. 1998, Cancino et al. 2003). The larvae settle and metamorphose spontaneously in 2-5 days after hatching (Leiva et al. 1998). Moreover, metamorphosis can be successfully induced by $\mathrm{KCl}$ soon after hatching (Gallardo \& Sánchez 2001), thus avoiding the complicated steps of hatchery feeding and larval management as in $C$. concholepas. Furthermore juveniles and adults are easily grown in laboratory conditions (Gutiérrez \& Gallardo 1999, Navarro et al. 2002, Gallardo et al. 2004, Carrasco et al. 2006). In relation to larval production, $C$. giganteus shows faster intracapsular embryonic development at high temperature $\left(18^{\circ} \mathrm{C}>9^{\circ} \mathrm{C}\right)$ but this is generally associated with a high embryonic mortality and low larval production (Cancino et al. 2003). Cancino et al. (2003) suggest that the high mortality and low hatching constrain of high temperature can be solved if egg capsule rearing at high temperature begins when embryos have reached advanced developmental stages. The present study was undertaken to determine the optimal combination of temperature and developmental stage for a successful (faster) larval production.

\section{Material and methods}

Whelks (Chorus giganteus) were collected from the Gulf of Arauco, Chile $\left(37^{\circ} 10^{\prime} \mathrm{S} ; 7^{\circ} 25^{\prime} \mathrm{W}\right)$ and maintained with ad libitum food (i.e. Mytilidae) in flow-through seawater at the Laboratorio Costero Lenga of the Universidad Católica de la Santísima Concepción. Three experiments, each one using egg capsules containing embryos at different stages, were conducted between March and December 1998. One or two weeks after spawning, capsules were acclimated for 2, 3 or 4 weeks at $12 \pm 1{ }^{\circ} \mathrm{C}$ in experiments I, II and III, respectively and then incubated at temperatures of 12,15 or $18^{\circ} \mathrm{C}$ until hatching. In each experiment, embryonic stages were classified as early cleavage stage (ES-embryos; Exp I), late stage (LS-embryos, Exp II) and trochophore post nurse-egg ingestion stage (TPI-embryos; Exp III), characterised by total ingestion of nurse-egg and by initiation of protoconch calcification according to González \& Gallardo (1999). One hundred and seventy three, 585 and 273 capsules were used in experiments I,
II, and III, respectively. Capsules were distributed almost equally in two replicate treatments in Exp I and in three replicate treatments in Exp II and III.

When the hatching process began in each experiment, both the daily number of capsules hatched and the number of larvae released were determined. The median hatching time (MHT; time taken for release $50 \%$ of larvae or $50 \%$ of capsules hatched) was registered at each temperature. In all experiments, the numbers of normal and abnormal hatching larvae were also determined. A larva was considered to be 'normal' if it showed four fully developed velar lobes and a calcified protoconch characterized by a dark brown colour. Finally, the probability of releasing a normal veliconch larva $\left(\mathrm{P}_{\mathrm{RL}}\right)$ was calculated for the three experiments from the following equations:

$$
\mathrm{P}_{\mathrm{RL}}=\mathrm{P}_{\mathrm{H}} \mathrm{x}_{\mathrm{PN}}
$$

where $\mathrm{P}_{\mathrm{H}}$ is the egg capsule hatching probability and $\mathrm{P}_{\mathrm{N}}$ is the probability of generating a normal larva per capsule. $\mathrm{P}_{\mathrm{H}}$ was determined as the ratio of spontaneously hatching capsules over the initial number of capsules in the experiment; $\mathrm{P}_{\mathrm{N}}$ was determined as the ratio of normal veliconch larvae hatched over the total number of larvae in each egg capsule.

The estimates of different parameters for each temperature were compared using a one way analysis of variance (ANOVA) and a posteriori Tukey test, when appropriate. The combined effect of temperature and initial embryonic stage on the probability of a normal veliconch larva being released (P3) was tested using a two-way analysis of variance (ANOVA).

\section{Results}

\section{Time and success in hatching}

Increased temperature accelerated the rate of embryonic development, and lowered the hatching time in all experiments (Table 1). For example, time to hatching 50\% of larvae was delayed by nearly 30 days in $12^{\circ} \mathrm{C}$ compared with $18^{\circ} \mathrm{C}$ in experiment II (Fig. 1).

The percentage of hatched capsules significantly decreased as temperature increased, in experiments I and II $(\exp \mathrm{I}, \mathrm{F}(2.3)=108 ; P<0.01 ; \exp \mathrm{II}, \mathrm{F}(2.6)=5.14 ; P$ $<0.05$; Fig. 2). This suggested that successful embryonic development in $C$. giganteus was restricted in $18^{\circ} \mathrm{C}$. However, deleterious effects of the high temperature were absent when this was applied to capsules containing embryos in the ingesting trochophore stage (exp III), where a similar percentage of hatched capsules were obtained at all temperatures $(\mathrm{F}(2.6)=0.73 ; P=0.51$, Fig. 2). 
Table 1

Hatching time of $C$. giganteus larvae in each experiment as function of temperature. IHT= Initial hatching time; MHT = median hatching time (time taken for release $50 \%$ of larvae or capsules hatched);

$$
\text { LHT = Last hatching time }
$$

Tiempo de eclosión de larvas de $C$. giganteus en cada experimento en función de la temperatura. IHT = Tiempo inicial de eclosión; MHT = Tiempo medio de eclosión (tiempo requerido para que el $50 \%$ de

las larvas o cápsulas eclosione); LHT = Tiempo de la última eclosión

\begin{tabular}{|c|c|c|c|c|c|c|c|c|c|}
\hline \multirow[t]{2}{*}{$\begin{array}{c}\text { Culture } \\
\text { temperature }\end{array}$} & \multicolumn{3}{|c|}{$\begin{array}{l}\text { Experiment } 1 \\
\text { (ES-embryos) }\end{array}$} & \multicolumn{3}{|c|}{$\begin{array}{l}\text { Experiment } 2 \\
\text { (LS-embryos) }\end{array}$} & \multicolumn{3}{|c|}{$\begin{array}{l}\text { Experiment } 3 \\
\text { (TPI-embryos) }\end{array}$} \\
\hline & IHT & MHT & LHT & IHT & MHT & LHT & IHT & MHT & LHT \\
\hline $12^{\circ} \mathrm{C}$ & 68 & 78 & 85 & 77 & 87 & 94 & 62 & 68 & 70 \\
\hline $15^{\circ} \mathrm{C}$ & 64 & 68 & 86 & 59 & 64 & 71 & 53 & 56 & 68 \\
\hline $18^{\circ} \mathrm{C}$ & 60 & 63 & 86 & 57 & 58 & 69 & 53 & 54 & 62 \\
\hline
\end{tabular}

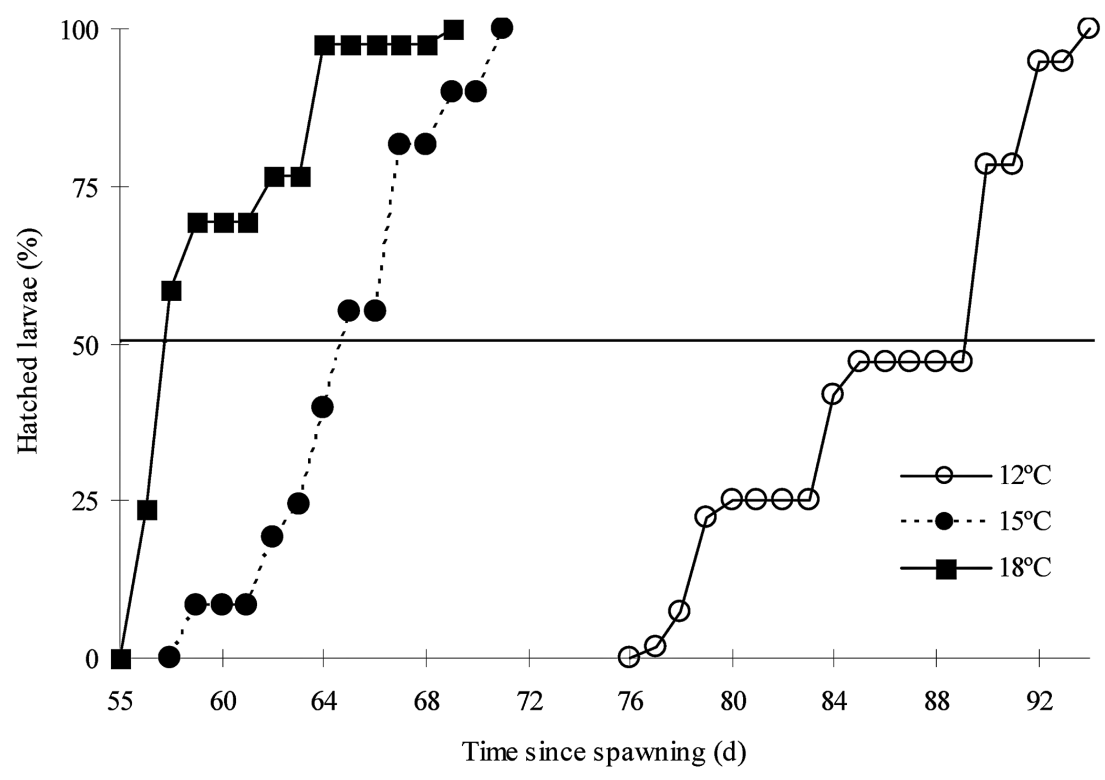

Figure 1

Effect of temperature on the hatching time of $C$. giganteus larvae in experiment II. Time since spawning refers to days after the egg capsules were laid. MHT $=$ median hatching time (time taken for release $50 \%$ of larvae or capsules hatched)

Efecto de la temperatura sobre el tiempo de eclosión larval de $C$. giganteus en el experimento II.

Tiempo se refiere a los días después de la postura de las cápsulas. MHT = Tiempo medio de eclosión (tiempo requerido para que el $50 \%$ de las larvas o cápsulas eclosione 


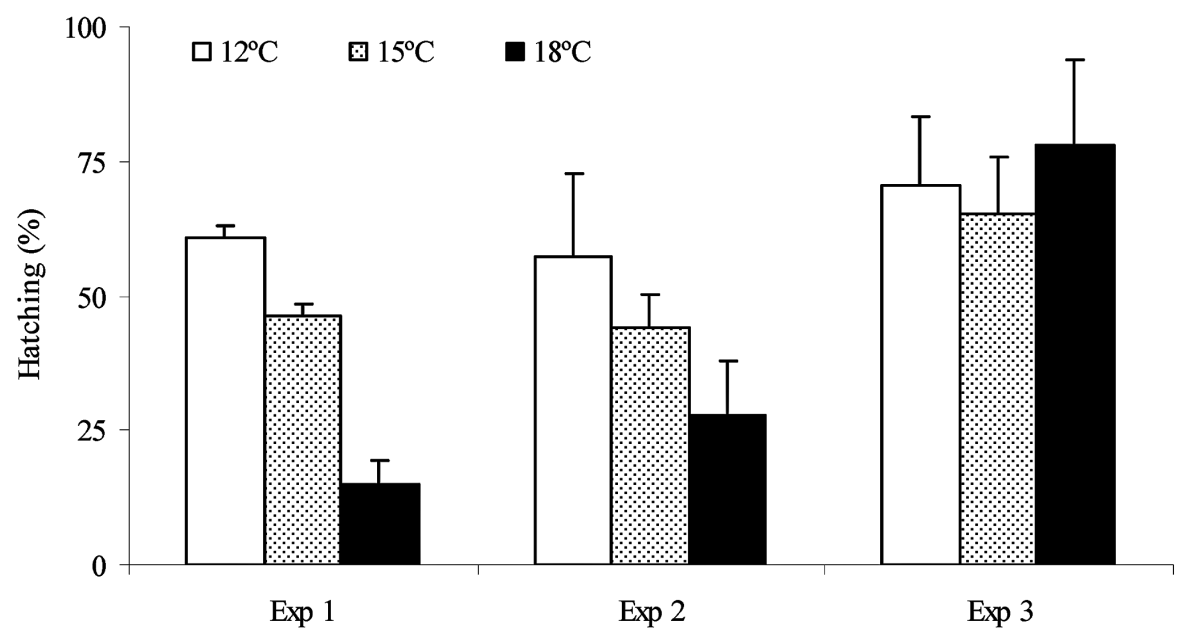

Figure 2

Effect of temperature on the percentage of hatched $C$. giganteus capsules in each experiment. Exp. I started with ovicapsules containing embryos in early cleavage stage, Exp. II started with embryos in late cleavage stage, and Exp. III started with trochophore post nurse-egg ingestion stage. Values are shown as mean \pm 1 SD $(n=3)$

Efecto de la temperatura sobre el porcentaje de cápsulas eclosionadas de $C$. giganteus en cada experimento.

Exp. I comenzó con cápsulas que contenían embriones en segmentación temprana, Exp. II comenzó con embriones en segmentación avanzada, y Exp. III comenzó con embriones en estado de trocófora post ingestión de huevos nutricios. Los valores son mostrados como el promedio $\pm 1 \mathrm{DE}(\mathrm{n}=3)$

\section{Table 2}

Total number of cultured $C$. giganteus capsules, percentage of hatchling, number of hatched larvae and percentage of abnormal embryos in each experiment as a function of temperature

Número total de cápsulas cultivadas de C. giganteus, porcentaje de eclosión, número de larvas eclosionadas y porcentaje de embriones anormales en cada experimento como función de la temperatura

\begin{tabular}{cccccc}
\hline \multicolumn{1}{c}{ Stage } & Temp. $\left({ }^{\circ} \mathrm{C}\right)$ & Total $\mathrm{N}^{\circ}$ of capsules & \% hatchling & $\begin{array}{c}\mathrm{N}^{\circ} \text { of hatched larvae } \\
\text { per replicate }\end{array}$ & $\begin{array}{c}\text { \% of abnormal } \\
\text { embryos }\end{array}$ \\
\hline ES-embryos & 12 & 28 & $61 \pm 2$ & $120 \pm 56$ & $14 \pm 3$ \\
& 15 & 20 & $46 \pm 2$ & $81 \pm 42$ & $26 \pm 1$ \\
LS-embryos & 18 & 6 & $15 \pm 5$ & $26 \pm 17$ & $46 \pm 3$ \\
& 12 & 76 & $57 \pm 16$ & $3,302 \pm 296$ & $8 \pm 1$ \\
TPI-embryos & 15 & 48 & $28 \pm 10$ & $2,857 \pm 359$ & $12 \pm \pm 1$ \\
& 18 & 14 & $70 \pm 13$ & $564 \pm 95$ & $13 \pm 11$ \\
& 15 & 17 & $65 \pm 11$ & $631 \pm 259$ & $20 \pm 1$ \\
& 18 & 12 & $78 \pm 16$ & $466 \pm 139$ & $17 \pm 4$ \\
\hline
\end{tabular}




\section{Embryonic abnormalities and larval production}

As temperature was increased the total larval production decreased in experiments I and II (Table 2). The total number of veliconch larvae was reduced from 3,373 at $12^{\circ} \mathrm{C}$ to only 156 in $18^{\circ} \mathrm{C}$ and from 9,156 at $12^{\circ} \mathrm{C}$ to 3,505 at $18^{\circ} \mathrm{C}$ in experiment I and II, respectively. The negative effect of high temperature on larval production decreased when the embryos were subjected to higher temperature after the ingesting trochophore stage had been reached. Accordingly, in experiment III a similar number of veliconch larvae were produced at the three temperatures (Table 2). Both, temperature and the initial embryonic stage affected the proportion of normal to abnormal veliconch larvae generated (Fig 3). The percentage of abnormal larvae increased with increase in temperature; significant differences were found in experiment $\mathrm{I}(\mathrm{F}(2.6)$ $=5.14 ; P<0.05)$, and II $(\mathrm{F}(2.6)=65.9 ; P<0.001)$. However, in experiment III there were no significant differences among the numbers of normal or abnormal larvae generated at the three temperatures $(\mathrm{F}(2.6)=0.79$; $P=0.49$ ) (Fig 3). Thus the probability of producing and releasing normal veliconch larvae $\left(\mathrm{P}_{\mathrm{RL}}\right)$ was significantly affected by the combined effect of temperature and embryonic stage at the initiation of the culture (Table 3 ).
A similar larval production could be obtained at 12, 15 or $18^{\circ} \mathrm{C}$ when the embryos are reared in high temperature from trochophore post ingestion stage (Fig. 4).

\section{Discussion}

The present study confirms that an accelerated embryonic development in Chorus giganteus at a high temperature constrains other physiological processes resulting in a reduced probability for reaching the veliconch larval stage. In other marine snails, increasing temperature generally accelerated the rate of shell growth and decreased the number of days required from larval release to spontaneous metamorphosis (Pechenik \& Lima 1984, Lima \& Pechenik 1985). This could be a desired effect for rearing in hatchery conditions, since shortening the time of intracapsular development may reduce culture costs. However, in $C$. giganteus the physiological cost of faster intracapsular embryonic development at $18^{\circ} \mathrm{C}$ led to the production of veliconch larvae of smaller size and fewer in number, as well as to the production of a high percentage of abnormal larvae and a lower spontaneous capsule hatching.

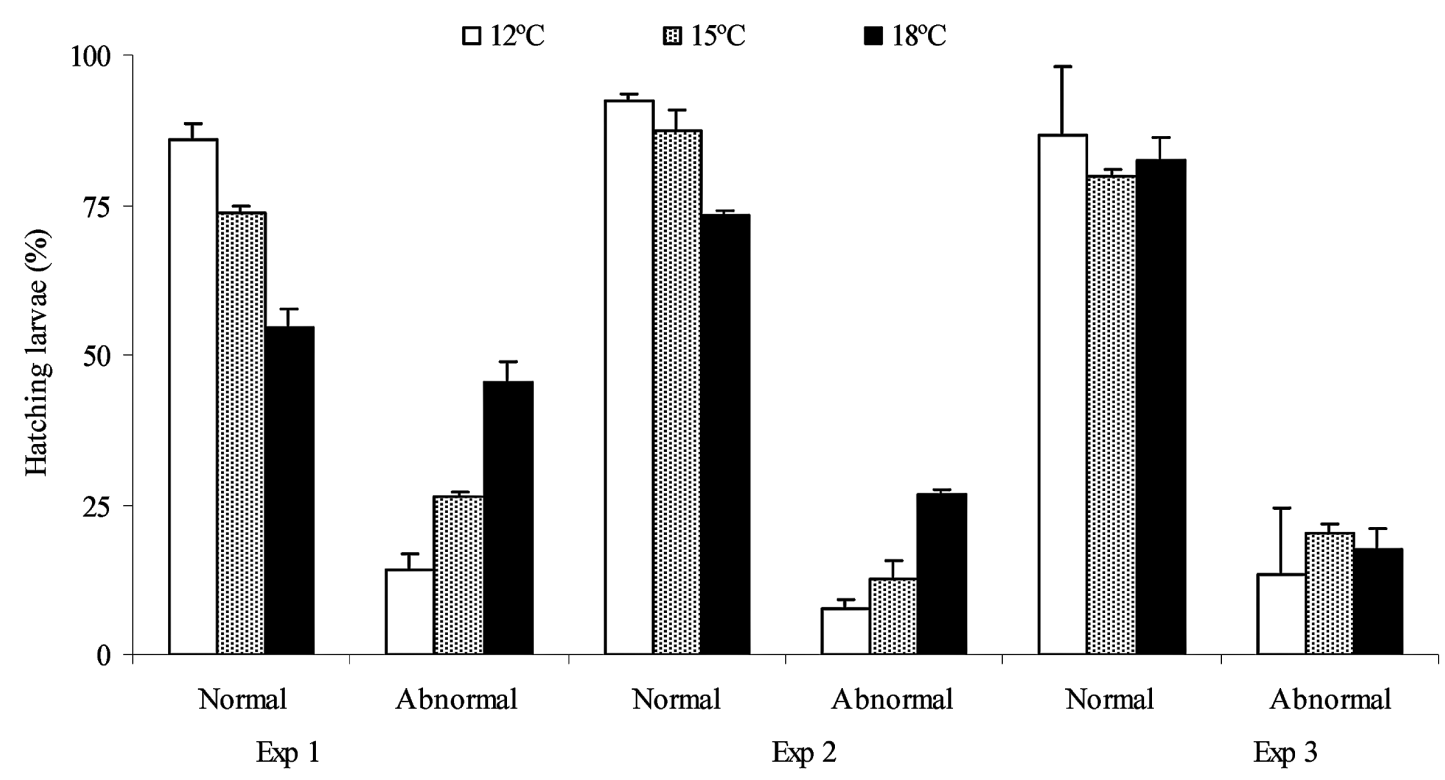

Figure 3

Effect of temperature on the proportion of normal and abnormal hatched larvae of $C$. giganteus in experiments I, II, and III. Values are shown as mean \pm 1 SD $(n=3)$

Efecto de la temperatura sobre la proporción de larvas eclosionadas normales y anormales de $C$. giganteus en los experimentos I, II y III. Los valores son mostrados como el promedio $\pm 1 \mathrm{DE}(\mathrm{n}=3)$ 
Table 3

Two-way ANOVA on the effects of temperature and initial embryonic stage on the probability of producing and releasing normal larvae in $C$. giganteus

Análisis de varianza (ANDEVA) de dos vías para los efectos de la temperatura y del estado de desarrollo sobre la probabilidad de producir y liberar larvas normales de $C$. giganteus

\begin{tabular}{lrrrc}
\hline \multicolumn{1}{c}{ Source of Variation } & DF & MS & \multicolumn{1}{c}{$F$} & $P$ \\
\hline Initial embryonic stage & 2 & 0.13 & 154 & $<0.001$ \\
Temperature & 2 & 0.19 & 228 & $<0.001$ \\
T x E & 4 & 0.05 & 61 & $<0.001$ \\
Error & 18 & & & \\
\hline
\end{tabular}

DF: Degree of freedom; MS: Mean square; F: F statistic; $P$ : Probability

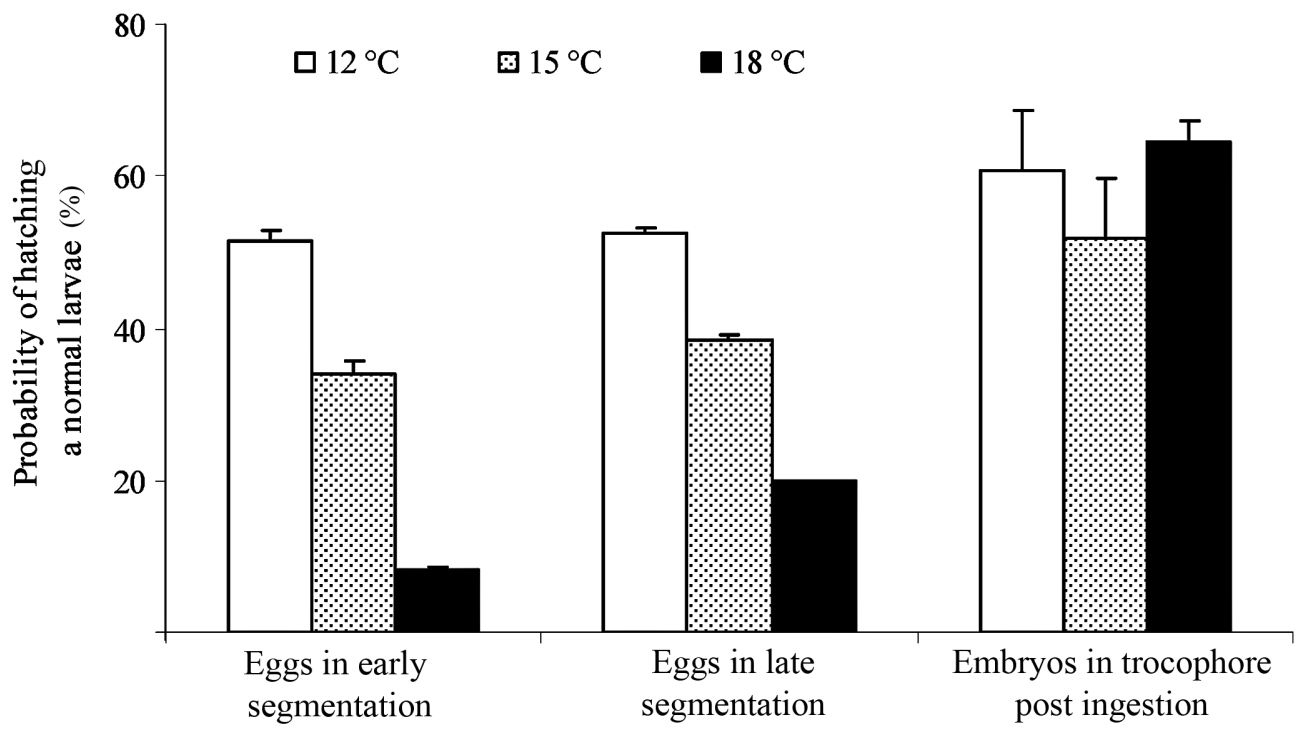

Figure 4

Probability of producing and releasing normal larvae (P3) of $C$. giganteus as a function of the combined effects of temperature and initial embryonic stage at which culture started. Values are shown as mean \pm 1 SD $(n=3)$

Probabilidad de producir y liberar larvas normales (P3) de C. giganteus en función del efecto combinado de la temperatura y del estado de desarrollo embrionario inicial de cultivo. Los valores son mostrados como el promedio $\pm 1 \mathrm{DE}(\mathrm{n}=3)$ 
The constraints imposed on $C$. giganteus by temperature depend on the developmental stage at which the higher temperature was applied. We have shown that increasing temperature from 12 to $18^{\circ} \mathrm{C}$ did not affect the embryonic development when high temperature was applied after the post ingestion trochophore stage. This suggests that $18^{\circ} \mathrm{C}$ was not a limiting temperature for $C$. giganteus developing after nurse egg ingestion. A great number of nurse eggs were not consumed by other embryos when high temperature was applied early after spawning. These nurse eggs were agglutinating within capsule till hatching. This phenomenon was infrequent at $15^{\circ} \mathrm{C}$ and never happened when development occurred at $12^{\circ} \mathrm{C}$. Thus, the negative effects of higher temperature observed in the present study are likely to be due to constraints in the intake of nurse eggs. The abnormal larvae probably consume only a few eggs compared to normal larvae. Gonzalez \& Gallardo (1999) described a high variability in the nurse egg ingestion by embryo of Chorus giganteus at $15^{\circ} \mathrm{C}$ (mean: $13.7 \pm 6.5$ nurse egg, minimum: 1, maximum 36). Further studies are required to determine how increased temperature interferes with nurse egg consumption.

The present results also contribute to understand the factors controlling spontaneous capsule hatching. In molluscs ovicapsule plug degradation seems to be a gradual process. There are three main mechanisms by which gastropod larvae are released from the capsules: (a) osmotically induced uptake of water (Hawkins \& Hutchinson 1988, Kennedy \& Keegan 1992), (b) direct mechanical action of the enclosed embryos on the opercule (Vaughn 1953), and (c) chemical dissolution of the opercule (Pechenik 1975). Mechanisms (b and c) have been reported as one of the hatching mechanisms used by Chorus giganteus (Leiva et al. 1998, González \& Gallardo 1999). We show that high number of abnormal embryos was associated with a reduced larval hatching. It was frequently observed at $18^{\circ} \mathrm{C}$, so spontaneous larval hatching from ovicapsules was prevented.

The present results must be, however, evaluated in relation to the origin of the parental broodstock. Eggs produced by $C$. giganteus in this study may have been adapted to lower temperature ranges given their origin in the Gulf of Arauco which is subject to low temperatures produced by the Humboldt Current. Populations from areas with different thermal conditions may respond differently to temperature variation due to local genetic differences produced by the low larval dispersal typical of the species (Gajardo et al. 2002).
We conclude that the conditions for rearing ovicapsules of $C$. giganteus, with the aim of maximising the production of veliconch larvae in the shortest possible time should include rearing at low temperature $\left(12^{\circ} \mathrm{C}\right)$ by 21 days until the post ingestion trocophore stage has been reached, followed by rearing at $15^{\circ} \mathrm{C}-18^{\circ} \mathrm{C}$ during 36 days until larval hatching takes place.

\section{Acknowledgments}

This research was financed by the 'Programa Acuicultura y Biotecnologia Marina', FONDAP Chile. We are particularly thankful of the important review made by two anonymous reviewers.

\section{Literature cited}

Cancino JM, JA Gallardo \& F Torres. 2003. Combined effects of dissolved oxygen concentration and water temperature on embryonic development and larval shell secretion in the marine snail Chorus giganteus (Gastropoda: Muricidae). Marine Biology 142: 133-139.

Carrasco CA, JM Navarro \& GE Leiva. 2006. Biochemical composition and tissue weight of Chorus giganteus (Gastropoda: Muricidae) exposed to different diets and temperatures during reproductive conditioning. Interciencia 31: $376-381$.

Disalvo L. 1988. Observations on the larval and postmetamorphic life of Concholepas concholepas (Bruguiere, 1979) in laboratory culture. The Veliger 30: 358-368.

Disalvo L \& M Carriker. 1994. Planktonic, metamorphic, and early behavior of the Chilean loco Concholepas concholepas (Muricidae, Gastropoda, Mollusca). Journal of Shellfish Research 13: 57-66.

Gajardo G, JM Cancino \& J Navarro. 2002. Genetic variation and population structure in the marine snail Chorus giganteus (Gastropod: Muricidae), an overexploited endemic resource from Chile. Fisheries Research 55: 329333.

Gallardo CS. 1981. Posturas y estadios de eclosión del gastrópodo muricidae Chorus giganteus (Lesson, 1829). Studies on Neotropical Fauna and Environment 16: 35-44.

Gallardo CS \& KA Sánchez. 2001. Induction of metamorphosis and its effect on the growth and survival of postmetamorphic juveniles of Chorus giganteus (Gastropoda: Muricidae). Aquaculture 201: 241-250.

Gallardo CS, MA Díaz \& C Varela. 2004. Growth and survival of early juvenile trumulco snail Chorus giganteus (Gastropoda: Muricidae) fed two prey species. New Zealand Journal of Marine and Freshwater Research 38: 767-773.

González K \& CS Gallardo. 1999. Embryonic and larval development of the muricid snail Chorus giganteus (Lesson, 1829) with an assessment of the developmental nutrition source. Ophelia 51: 77-92. 
Gutiérrez RM \& CS Gallardo. 1999. Prey attack, food preferences and growth in juveniles of the edible muricid snail Chorus giganteus. Aquaculture 174: 69-79.

Hawkins L \& S Hutchinson. 1988. Egg capsule structure and hatching mechanism of Ocenebra erinacea (L.) (Prosobranchia: Muricidae). Journal of Experimental Marine Biology and Ecology 119: 269-283.

Kennedy JJ \& BF Keegan. 1992. The encapsular developmental sequence of the mesogastropod Turritella comunis (Gastropoda: Turritelidae). Journal of the Marine Biological Association of the United Kingdom 72: 783805 .

Leiva GE, JE Muñoz \& J Navarro. 1998. Desarrollo intracapsular y mecanismos de eclosión del caracol trumulco Chorus giganteus (Lesson, 1829) (Gastropoda: Muricidae), bajo condiciones de laboratorio. Revista Chilena de Historia Natural 71: 157-167.

Lima G \& J Pechenik. 1985. The influence of temperature on growth rate and length of larval life of the gastropod, Crepidula plana. Journal of Experimental Marine Biology and Ecology 90: 55-71.
Martínez G, V López, L Mettifogo, JM Cancino. 2008. Energy source utilization by embryos and larvae of the muricid snail Chorus giganteus (Lesson, 1829). Journal of Experimental Marine Biology and Ecology 354: 65-80.

Navarro JM, GE Leiva, CS Gallardo \& C Varela. 2002 Influence of diet and temperature on physiological energetics of Chorus giganteus (Gastropoda: Muricidae) during reproductive conditioning. New Zealand Journal of Marine and Freshwater Research 36: 321-332.

Pechenik JA. 1975. The escape of veligers from the egg capsules of Nassarius obsoletus and Nassarius trivittatus (Gastropoda, Prosobranchia). The Biological Bulletin 149: 580-589.

Pechenik J \& G Lima. 1984. Relationship between growth, differentiation, and length of larval life for individually reared larvae of the marine gastropod, Crepidula fornicata. The Biological Bulletin 166: 537-549.

Vaughn G. 1953. Effects of temperature on hatching and growth of Limnaea atagnalis appressa Say. The American Midland Naturalist 25: 407-408.

Recibido el 26 de junio de 2009 y aceptado el 21 de agosto de 2009 